\title{
CONSIDERATIONS ABOUT THE EXPERIENCE IN EXPERIMENTAL MICROSURGERY IN CATANIA UNIVERSITY
}

\author{
A. Di Cataldo, G. La Greca, F.S. Latteri, S. Puleo \\ University of Catania, \\ Viale Odorico da Pordenone 5, 95128 Catania, Italy
}

In the 1980s and 1990s Microsurgery has had a great diffusion in Italy. Our group, who worked in University of Catania, Sicily, got in touch with Sun Lee, the father of Experimental Microsurgery, and applied actively the microsurgical techniques both in the experimental and clinical field.

Several Courses have been organized in Catania to involve young doctors who have been charmed by this new surgical branch.

It is our opinion that in the present time Microsurgery could play an important role in the training of the general surgery residents. An experimental microsurgical training, together with simulators, could guarantee a more complete training of the residents, helping them to be familiar with surgical instruments and suture materials, improving their skill in performing microvascular anastomoses (carotid and femoral arteries) and more complex surgical operations (portocaval shunt) and leading them to a valid research activity.

Keywords:

Conflict of interest:

Financial disclosure:

For citation:

\section{Microsurgery, training, General Surgery.}

the authors declare the absence of obvious and potential conflicts of interest related to the publication of this article.

Di Cataldo A., La Greca G., Latteri F.S., Puleo S. Considerations about the experience in experimental microsurgery in Catania University. Issues of Reconstructive and Plastic Surgery. 2020;24(1):73-76. doi: 10.52581/1814-1471/76/8

\section{ОПЫТ ЭКСПЕРИМЕНТАЛЬНОЙ МИКРОХИРУРГИИ В КАТАНИЙСКОМ УНИВЕРСИТЕТЕ}

\author{
А. Аи Катальдо, Г. Аа Грека, Ф.С. Ааттери, С. Пумео \\ Университет Катании \\ 2. Катания, Италия
}

В 1980-1990-х гг. микрохирургия получияа в Италии широкое распространение. Наша группа, работавшая в Университете Катании на Сицилии, связалась с Сун Аи, отцом экспериментальной микрохирургии, и активно начала применять микрохирургические методы как в экспериментальной, так и в клинической работе.

В Катании было организовано несколько курсов дмя молодых врачей, интересующихся этим новым направлением в хирургии.

По нашему мнению, в настоящее время микрохирургия может играть важную роль в обучении молодых врачей, специализирующихся по общей хирургии. Экспериментальная микрохирургическая подготовка с использованием симуляторов может гарантировать более полное обучение ординаторов, помогая им ознакомиться с хирургическими инструментами и шовными материалами, совершенствуя их навыки в выполнении микрососудистых анастомозов (сонная и беАренная артерии) и более сложных хирургических операций (портокавальный шунт) и способствует их к полноценной исслеАовательской деятельности.

Киючевые слова:

Конфмикт интересов:

$$
\text { микрохирургия, обучение, общая хирургия. }
$$

авторы подтвержАают отсутствие конфмикта интересов, о котором необходимо сообщить. 
Прозрачность финансовой деятельности:

Амя цитирования: никто из авторов не имеет финансовой заинтересованности в преАставленных материалах или методах.

Аи Катацьдо А., Аа Грека Г., Ааттери Ф.С., Пумео С. Опыт экспериментальной микрохирургии в Катанийском университете. Вопросы реконструктивной и пластической хирургии. 2020;24(1):73-76. doi: 10.52581/1814-1471/76/8
Professor Sun Lee is universally known as the father of Experimental Microsurgery and through his tireless activity all around the world has greatly helped in spreading it. Even though microsurgical techniques are nowadays not frequently adopted in the field of General Surgery, Microsurgery has had a great role in the surgical achievements of the last century, especially in Transplantation, Immunology and Vascular Surgery. The end-toside portocaval shunt performed for the first time by Lee in 1957 became a milestone and opened the way to transplantation models in rats [1]. The experimental models created by him have been the basis to study important topics: ischemiareperfusion effect, rejection, immunosuppression agents. Sun Lee has been very able to draw the attention of the young doctors and fascinate them through his incomparable skill.

In Italy many surgeons approached Microsurgery and carried out several teams and each of them dedicated itself to a specific field. Brunelli in Brescia worked especially on central and peripheral nerves, Fox in Milano studied the pathophysiology of varicocele and to treat it realized the microsurgical anastomosis between the spermatic vein and the saphenous vein [2]. In Genova Campisi carried on the experience of his mentor Tosatti in the surgery of lymphatics and realized many microsurgical techniques to solve the problems linked to primitive and secondary lymphedema [3]. In Rome Gaspari and mostly Ortensi tried to apply microsurgical techniques in the clinical field (repair of lesion of laryngeal nerve after thyroidectomy, etc.). These surgeons not only applied the microsurgical techniques to selected fields, but at the same time organized many microsurgical courses to involve young doctors who, almost always, were charmed by this new surgical branch, so that in Italy a diffuse interest in Microsurgery rose and developed, culminating in many crowded scientific meetings of the Italian Society of Microsurgery, where interesting papers have been presented.

In University of Catania, Sicily, Professor Rodolico realized the potential importance of the role played by Microsurgery in the hands of the general surgeon and induced many of his pupils (Puleo, Di Cataldo, Li Destri, Trombatore) to learn the microsurgical techniques. For many years a tight collaboration between Catania and Lee has been set up and one of us (A.D.) attended for four months the Microsurgical Laboratory of San Diego, California, where Lee welcomed surgeons coming from every part of the world and teached them with great passion and enthusiasm. In our department, guided by the supporting approval of our mentor, between 1983 and 1986 we did three Microsurgical Courses to allow young doctors to acquire a basic microsurgical knowledge [4].

The Courses in Catania have been organized according to the model used by Lee in San Diego.

For one week, Monday through Friday, after a short oral introduction, each student received one operating microscope with a viewer binocular apparatus, so that the instructor was able to observe his/her performance and correct him/her. At first, the student used a practice disc to do suturing incision on a thin rubber shit and working on simulated blood vessels. After this preliminary stage, the students were instructed to perform in the rat end-to-end and end-to-side carotid anastomosis, then femoral artery and femoral vein anastomosis. Other exercises were vasovasostomy and sciatic nerve suture. The last day end-to-side portocaval shunt was shown, and we noted that this experimental exercise was the preferred one by residents in general surgery.

This intense microsurgical activity leaded us to use microsurgical techniques both in the experimental and clinical field.

In the experimental field among the topics that have been deeply studied we would like to remember the pathophysiological alterations after portocaval shunt, both end-to-side and side-to-side [5-7], some technical aspects of pancreas transplantation in the rat [8] and the importance of Microsurgery in the training of the general surgeon [9].

In the clinical field the microsurgical techniques have been used by us especially in the treatment of infertility caused by varicocele: in our department many patients have been treated by microsurgical anastomosis between spermatic vein and saphenous or epigastric vein and their results have been published [10]. Other clinical applications performed by our team have been testicle auto-transplantation in high undescended testis and microsurgical duct-to-mucosa pancreaticojejunostomy after pancreaticoduodenal resection.

The International Society for Experimental Microsurgery has been founded in 1992 in Rome 
and our Department joined actively its Meetings that have been held regularly every two years. It has been a good chance to follow the microsurgical experimental studies performed all around the World and to exchange the obtained promising results. We think that the actual problems in this Society is to guarantee the replacement of the old members through the acquirement of young doctors. It will be our task to mold these young doctors and to induce them to the fantastic world of Microsurgery.

With this didactic perspective and in the possibility to use a modern laboratory of preclinical in vivo research realized in our University, we organized in Catania University a short but intensive experimental microsurgical course in October 9-11, 2018.

In order to obtain a high-quality course, we asked for the collaboration of the ISEM President elected Professor Mihai Oltean, Associate Professor at Gothenburg University, and Professor Mats Hellstrom, both working at the laboratory for transplantation and regenerative medicine at Sahlgrenska University Hospital, attended also by some of our students. They presented interesting lectures and together with some teachers of our University contributed as instructors to the practical stage of the course.

The course took place with three theoretical sessions in the morning, open to all students and postgraduates, during which various topics were covered such as the instrumental set for basic microsurgery, suturing materials and the principles and techniques in microvascular anastomosis, anatomy and physiology in rats and mice, anesthesia, analgesia and perioperative care in small animals, experimental models, etc.

In the afternoon of the three days, a small number of doctors were guided by the guest and local tutors in a practical training on microscope set-up, suturing and knotting in non-living models, dissection of various vessels in rats, anastomosis on femoral vessels, abdominal surgical anatomy, dissection of inferior cava vein and aorta, microvascular aorta anastomosis etc.

The enthusiasm and the convinced participation shown by all the students has been the best reward for our organizational efforts, in the awareness of having offered them, as our duty, the opportunity to broaden their knowledge and stimulate their interest in research and Microsurgery (Illustration).

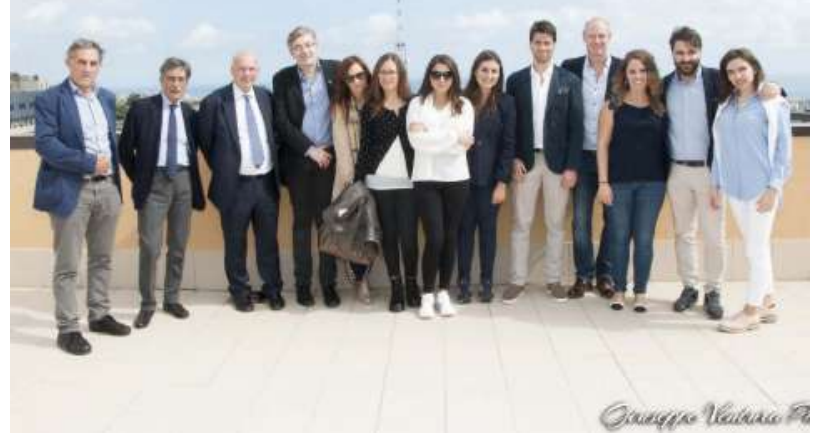

Dr. G. La Greca, S. Puleo, A. Di Cataldo, M. Oltean and the residents who attended the Course

Аоктора Аж. Аа Грека, С. Пулео, А.Аи Катальдо и М. ОАтин с резидентами курса

Realistically we cannot think that experimental microsurgery and its subsequent clinical applications could have a future without the involvement of the younger generations who will, gradually, must replace those of us in the past believed in the value of the role of the experimental research and microsurgery in the training of a surgeon.

What it could be the actual role of Microsurgery in the activity of the general surgeons? In the modern view of General Surgery, we think that Microsurgery could play an important role in the training of the young residents. It has been demonstrated that different factors do not guarantee an adequate training for residents in General Surgery: limitation of working hours, the demand for increased operating room efficiency and medico-legal problems [11]. We agree that the use of simulators could limit the unfavorable effects of these factors and improve the quality of the training, but we think that an experimental microsurgical training could be also very useful to further better the technical skill of the residents.

Through a basic microsurgical Course [12] the resident learns how to perform many surgical procedures: arterial and venous micro anastomoses, portocaval shunt (end-to-side and side-to-side) [13]. After this initial stage he/she can repeat many times the same surgical exercise and after a relatively short period of time gain an undeniable mastery of the technique. This microsurgical experience is valid not only from the technical point of view to increase the skill, but it also could be very important to have the opportunity to perform interesting pathophysiological studies that can be used in a research activity [14].

\section{REFERENCES}

1.Lee S.H., Fischer B. Porto-caval shunt in the rat. Surgery. 1961; 50: 668-675.

2. Fox U., Romagnoli G., Colombo F. The microsurgical drainage of the varicocele. Fert Steril. 1984; 41: $475-478$.

3. Campisi C., Boccardo F. Frontiers in lymphatic microsurgery. Microsurgery. 1998; 18: 462-471.

4. Di Cataldo A., Puleo S., Rodolico G. Three microsurgical courses in Catania. Microsurgery. 1998; 18: $449-453$. 
5.Di Cataldo A., Li Destri G., Scilletta B., Trombatore G., Desiderio C., Ferro A., Castorina S., Racalbuto A., Puleo S. Ultrastructural changes of the gastric mucosa after portacaval shunt in the rat. A new model to study $\mathrm{H} 2$ receptor antagonists? Surg Res Comm. 1990; 7: 135-139.

6. Di Cataldo A., Li Destri G., Scilletta B., Trombatore G., Rodolico M.S., Di Carlo I., Castorina S., Desiderio C., Minutolo V., Puleo S., Licata A. Corrélations probables entre les anomalies ultrastructurelles du système nerveux central et l'hyperammoniémie après anastomose porto-cave chez le rat. J Chir.1991; 128: 193-196.

7.Li Destri G., Scilletta B., Racalbuto A., Rodolico M., Celeste S., Ferro A., Rapisardo E., Matera M., Di Cataldo A. Alterations of the GAD activity in different cerebral areas in rats with chronic encephalopathy caused by portocaval shunt. Surg Res Comm. 1992; 11: 281-288.

8. Di Cataldo A., Puleo S., Li Destri G., Guastella T., Trombatore G., La Greca G., Leone F., Latteri F, Rodolico G. Pancreas transplantation in the rat using Lee's technique: a reliable model in experimental Microsurgery. J Invest Surg. 1989; 2: 159-167.

9. Di Cataldo A., Li Destri G., Trombatore G., Papillo B., Racalbuto A., Puleo S. Usefulness of microsurgery in the training of the general surgeon. Microsurgery. 1998; 18: 446-448.

10. Puleo S., Di Cataldo A., Li Destri G., Trombatore G., Guastella T., Di Benedetto A., Rodolico G. Microsurgical treatment of varicocele. Int Surg. 1989; 74: 253-256.

11. Di Cataldo A., Latino R., Perrotti S., Di Franco G., Gianardi D., Morelli L. Use of experimental Microsurgery to improve resident autonomy and training. J Am Coll Surg. 2020; 231: 606-607.

12. Tolba R.H., Czigani Z., Lujan S.O., Oltean M., Axelsson M., Akelina Y., Di Cataldo A., Miko I., Furka I., Dahmen U., Kobayashi E., Ionac M., Nemeth N. Defining standards in experimental microsurgical training: recommendations of the European Society for Surgical Research (ESSR) and the International Society for Experimental Microsurgery (ISEM). Eur Surg Res. 2017; 58: 246-262.

13. Di Cataldo A., La Greca G., Rodolico M., Candiano C., Li Destri G., Puleo S. Experimental models in Microsurgery. Microsurgery. 1998; 18: 454-459.

14. Lanteri R., Acquaviva R., Di Giacomo C., Caltabiano R., Li Destri G., Vanella L, Santangelo M., Lanzafame S., Di Cataldo A. Heme oxygenase 1 expression in postischemic reperfusion liver damage: effect of L-arginine. Microsurgery. 2006; 26: 25-32.

Поступила в редакиию 20.12.2020, утверждена к печати 18.02.2021 Received 20.12.2020, accepted for publication 18.02.2021

Information about authors:

Antonio Di Cataldo*, MD, Hon FACS, Full Professor of General Surgery, the Department of Surgery, University of Catania, Catania, Italy.

Viale Odorico da Pordenone 5, 95128 Catania, Italy.

Gaetano La Greca, MD, FACS, PhD, Associate Professor of General Surgery, the Department of Surgery, University of Catania, Catania, Italy.

F.S. Latteri, MD, pHd, University Researcher, the Department of Surgery, University of Catania, Catania, Italy.

Stefano Puleo, MD, Full Professor of General Surgery, the Department of Surgery, University of Catania, Catania, Italy.

\section{Сведения об авторах:}

Антонио Аи КатальАо*, MD, заслуженный специалист FACS, профессор общей хирургии, кафедра хирургии Университета Катании (г. Катания, Итамия).

Viale Odorico da Pordenone 5, 95128, Катания, Италия.

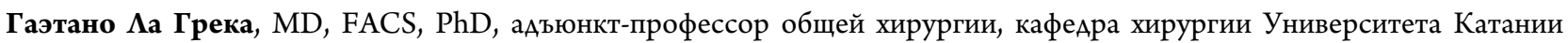
(г. Катания, Италия).

Ф.С. Ааттери, MD, pHd, научный сотрудник кафеАры хирургии Университета Катании (г. Катания, Италия).

Стефано Пумео, MD, профессор общей хирургии, кафеАра хирургии Университета Катании (г. Катания, Италия). 